\title{
The fractionation of nitrogen and oxygen isotopes in macroalgae during the assimilation of nitrate
}

\author{
P. K. Swart ${ }^{1}$, S. Evans ${ }^{1, *}$, T. Capo ${ }^{2}$, and M. A. Altabet $^{3}$ \\ ${ }^{1}$ Division of Marine Geology and Geophysics, Rosenstiel School of Marine and Atmospheric Sciences, University of Miami, \\ 4600 Rickenbacker Causeway, Miami, Fl 33149, USA \\ ${ }^{2}$ Division of Marine Biology and Fisheries, Rosenstiel School of Marine and Atmospheric Sciences, University of Miami, \\ 4600 Rickenbacker Causeway, Miami, Fl 33149, USA \\ ${ }^{3}$ School for Marine Science and Technology, University of Massachusetts Dartmouth, New Bedford, MA 02744, USA \\ * now at: Department of Geosciences, Boise State University, 1910 University Drive, Boise, Idaho 83725-1535, USA
}

Correspondence to: P. K. Swart (pswart@rsmas.miami.edu)

Received: 27 March 2014 - Published in Biogeosciences Discuss.: 16 May 2014

Revised: 9 September 2014 - Accepted: 30 September 2014 - Published: 13 November 2014

\begin{abstract}
In order to determine and understand the stable isotope fractionation of ${ }^{18} \mathrm{O}$ and ${ }^{15} \mathrm{~N}$ manifested during assimilation of $\mathrm{NO}_{3}^{-}$in marine macro-benthic algae, two species (Ulva sp. and Agardhiella sp.) have been grown in a wide range of $\mathrm{NO}_{3}^{-}$concentrations $(2-500 \mu \mathrm{M})$. Two types of experiments were performed. The first was one in which the concentration of the $\mathrm{NO}_{3}^{-}$was allowed to drift downward as it was assimilated by the algae, between 24 hour replacements of media. These experiments proceeded for periods of between 7 and 10 days. A second set of experiments maintained the $\mathrm{NO}_{3}^{-}$concentration at a low steady-state value by means of a syringe pump. The effective fractionation during the assimilation of the $\mathrm{NO}_{3}^{-}$was determined by measuring the $\delta^{15} \mathrm{~N}$ of both the (i) new algal growth and (ii) residual $\mathrm{NO}_{3}^{-}$in the free-drift experiments after 0, 12, 24 and $48 \mathrm{~h}$. Modelling these data show that the fractionation during assimilation is dependent upon the concentration of $\mathrm{NO}_{3}^{-}$and is effectively 0 at concentrations of less than $\sim 2 \mu \mathrm{M}$. The change in the fractionation with respect to concentration is the greatest at lower concentrations $(2-10 \mu \mathrm{M})$. The fractionation stablizes between 4 and $6 \%$ at concentrations of between 50 and $500 \mu \mathrm{M}$. Although the $\delta^{18} \mathrm{O}$ and $\delta^{15} \mathrm{~N}$ values of $\mathrm{NO}_{3}^{-}$in the residual solution were correlated, the slope of relationship also varied with respect to $\mathrm{NO}_{3}^{-}$concentration, with slopes of greater than unity at low concentration. These results suggest shifts in the dominant fractionation mechanism of ${ }^{15} \mathrm{~N}$ and ${ }^{18} \mathrm{O}$ between concentrations of 1 and $10 \mu \mathrm{M}$ $\mathrm{NO}_{3}^{-}$. At higher $\mathrm{NO}_{3}^{-}$concentrations $(>10-50 \mu \mathrm{M})$, frac-
\end{abstract}

tionation during assimilation will lead to $\delta^{15} \mathrm{~N}$ values in algal biomass lower than the ambient $\mathrm{NO}_{3}^{-}$and ${ }^{15} \mathrm{~N}$ enrichments in the residual $\mathrm{NO}_{3}^{-}$.

\section{Introduction}

Nitrogen availability is an important factor in controlling algal growth in marine environments, representing a limiting nutrient throughout much of the global ocean (Dugdale and Wilkerson, 1986). In many studies, information on nitrogen sources and its cycling has been obtained by examining the ratio of the stable isotopes of nitrogen $\left({ }^{14} \mathrm{~N}\right.$ and $\left.{ }^{15} \mathrm{~N}\right)$ as well as oxygen $\left({ }^{18} \mathrm{O}\right.$ and $\left.{ }^{16} \mathrm{O}\right)$ in the case of $\mathrm{NO}_{3}^{-}$. Isotope ratios are expressed using the conventional "delta" notation $\left(\delta^{15} \mathrm{~N}\right.$ or $\left.\delta^{18} \mathrm{O}\right)$ in parts per thousand (\%o) deviation from the atmospheric $\mathrm{N}_{2}$ standard or, in the case of oxygen, from Vienna standard mean ocean water (VSMOW). During cycling of $\mathrm{NO}_{3}^{-}$, isotope fractionation takes place, as quantified by the associated fractionation factor $(\alpha)$. For algal $\mathrm{NO}_{3}^{-}$uptake, $\alpha$ can be calculated using Eq. (1). 
The term epsilon $(\varepsilon)$ is also commonly used and is related to $\alpha$ by Eq. (2).

$$
\begin{array}{r}
\alpha=\frac{\frac{{ }^{15} \mathrm{~N}}{{ }^{14} \mathrm{~N}_{\mathrm{NO}_{3}}}}{\frac{15 \mathrm{~N}}{{ }^{14} \mathrm{~N}_{\text {algae }}}} \\
\varepsilon=(\alpha-1) \times 1000
\end{array}
$$

The term $\varepsilon$ can refer to fractionation of either ${ }^{15} \mathrm{~N}\left({ }^{15} \varepsilon\right)$ or ${ }^{18} \mathrm{O}\left({ }^{18} \varepsilon\right)$ relative to the more abundant isotope of the element. In some of these processes, such as the fixation of atmospheric nitrogen, no significant isotopic fractionation takes place $\left({ }^{15} \varepsilon \sim 0.0 \%\right.$ ) (Hoering and Ford, 1960), and consequently the $\delta^{15} \mathrm{~N}$ of $\mathrm{N}_{2}$ fixing organisms is similar to that of atmospheric $\mathrm{N}_{2}$ ( $0 \%$ by convention). In other processes, such as the denitrification of $\mathrm{NO}_{3}^{-},{ }^{15} \varepsilon$ values are higher than 20\%o (Barford et al., 1999; Delwiche and Steyn, 1970; Granger et al., 2006; Miyake and Wada, 1971), leading to large increases in the $\delta^{15} \mathrm{~N}$ of the residual reservoir of $\mathrm{NO}_{3}^{-}$. While the $\delta^{15} \mathrm{~N}$ of microalgae has been studied in order to understand its use as a paleoceanographic proxy (Altabet, 1989; Altabet et al., 1991; Haug et al., 1998; Sigman et al., 2003), variations in the $\delta^{15} \mathrm{~N}$ of macroalgae have also been widely used as possible indicators of anthropogenic influences (Carballeira et al., 2013; Costanzo et al., 2001; Heaton, 1986). Generally speaking, nitrogen derived from sewage is isotopically enriched in ${ }^{15} \mathrm{~N}$, and it has been argued that even modest enrichments of ${ }^{15} \mathrm{~N}$ in macroalgae might reflect enhanced input from such sources (Lapointe et al., 2004). Other studies have shown that such enrichments could occur through normal processes including fractionation during assimilation (Lamb et al., 2012; Stokes et al., 2011) and that there are not always simple relationships between the input of anthropogenic wastes and $\delta^{15} \mathrm{~N}$ values (Viana and Bode, 2013).

Studies of isotope fractionation during the assimilation of dissolved inorganic nitrogen by marine microalgae have reported a wide range of values. In one study, reported ${ }^{15} \varepsilon$ values ranged from 0.7 to $23 \%$ for the assimilation of $\mathrm{NO}_{3}^{-}$ by Phaeodactylum tricornutum (Wada and Hattori, 1978), a marine diatom. Another study reported ${ }^{15} \varepsilon$ values between 2.2 and $6.2 \%$ or 12 different marine phytoplankton cultures kept at a $\mathrm{NO}_{3}^{-}$concentration of $100 \mu \mathrm{M}$ (Needoba et al., 2003). Other research also reports wide ranges in ${ }^{15} \varepsilon$ values for both $\mathrm{NO}_{3}^{-}$and $\mathrm{NH}_{4}^{+}$for a variety of different microalgae (Horrigan et al., 1990; Lajtha and Michener, 1994; Montoya et al., 1990; Wada and Hattori, 1978). At least part of these large ranges in ${ }^{15} \varepsilon$ values probably resulted from variations in experimental conditions and are perhaps artefacts resulting from differences in aeration, light and nutrient drawdown. In addition, changing nutrient concentration might be an important controlling parameter, and several studies have shown that microalgae show varying fractionation as a function of concentration (Hoch et al., 1992; Pennock et al., 1996; Waser et al., 1998) that is likely due to changes in physiology and perhaps uptake mechanism.
In contrast to microalgae, there have been relatively few studies of ${ }^{15} \mathrm{~N}$ fractionation in macroalgae. Some of these studies have relied on spiking the natural environment with high nitrate and ammonium concentrations (Teichberg et al., 2007), while others have used transplant experiments (Deutsch and Voss, 2006). Neither of these investigations reported ${ }^{15} \varepsilon$ values for fractionation during the assimilation of $\mathrm{NO}_{3}^{-}$. The study of Cohen and Fong (2005) grew the green algae Enteromorpha intestinalis under varying concentrations of $\mathrm{NO}_{3}^{-}$and $\mathrm{NH}_{4}^{+}$, and, although they did not report values for ${ }^{15} \mathrm{~N}$ fractionation, they concluded that the $\delta^{15} \mathrm{~N}$ of the algae was not dependent upon concentrations of dissolved inorganic nitrogen. These experiments used a combination of increases in $\mathrm{NO}_{3}^{-}$and $\mathrm{NH}_{4}^{+}$, with the lower $\mathrm{NO}_{3}^{-}$ concentration experiments containing high amounts of $\mathrm{NH}_{4}^{+}$ and vice versa. Under such experimental conditions it would have been difficult to isolate any potential concentration dependence upon fractionation manifested during assimilation. Given the possibility of a concentration dependence of ${ }^{15} \mathrm{~N}$ fractionation for $\mathrm{NO}_{3}^{-}$in microalgae, we revisit here whether such a dependency is found in macroalgae. We have used two different approaches over a range of different concentrations. In the first series of experiments, two species of macroalgae, Ulva sp. and Agardhiella sp, were grown over a range in nominal $\mathrm{NO}_{3}^{-}$concentrations of $10,50,100$ and $500 \mu \mathrm{M}$. As the algae within each culture consumed the $\mathrm{NO}_{3}^{-}$in the solution, the solutions were replaced every $24 \mathrm{~h}$. These were the so-called free-drift experiments. In the second set of experiments, $\mathrm{NO}_{3}^{-}$levels were maintained at a low level $(<2 \mu \mathrm{M})$ by continual addition from a syringe pump. Hence these experiments cover the range of $\mathrm{NO}_{3}^{-}$concentrations used in most previous experiments $(>100 \mu \mathrm{M})$ as well as those seen under natural conditions.

\section{Methods}

Samples of the green algae Ulva sp. and the rhodophyte algae Agardhiella sp. were collected from cultures held at the Aplysia Mariculture Laboratory's algal aquaculture facility (University of Miami). These species were maintained in a system of seven, $9000 \mathrm{~L}$ fiberglass tanks supplied with filtered seawater at a rate of $\sim 22 \mathrm{~L} \mathrm{~min}^{-1}$. Radiant energy and temperature are monitored constantly, and algal growth rates are optimized by adjusting nutrient levels weekly. These stocks are kept continually as a food source for other organisms in the facility. In preparation for these experiments the algal thalli were rinsed with filtered seawater and gently scrubbed to remove surface epiphytes. Prior to experimentation, the macroalgae were maintained within $2 \mathrm{~L}$ flasks at $26^{\circ} \mathrm{C}$ and approximately $100 \mu \mathrm{mol}$ photons $\mathrm{m}^{-2} \mathrm{~s}^{-1}$ for a 14-day acclimation period. During the acclimation period, filtered and autoclaved seawater was changed every 2 days, enriched to $500 \mu \mathrm{M} \mathrm{N}\left(250 \mu \mathrm{M} \mathrm{NaNO}{ }_{3}\right.$ and $\left.250 \mu \mathrm{M} \mathrm{NH} \mathrm{N}_{4} \mathrm{Cl}\right)$ and $44 \mu \mathrm{M} \mathrm{KH}_{2} \mathrm{PO}_{4}$, with $f / 2$ medium supplements of $\mathrm{B}$ 
Table 1. Changes in the $\delta^{15} \mathrm{~N}$ and $\delta^{18} \mathrm{O}$ of $\mathrm{NO}_{3}^{-}$during the Ulva experiments.

\begin{tabular}{|c|c|c|c|c|c|c|c|c|}
\hline \multirow{3}{*}{ Time } & \multicolumn{4}{|c|}{ Ulva sp. } & \multicolumn{4}{|c|}{ Agardiella sp. } \\
\hline & $\mathrm{NO}_{3}^{-}$ & $\begin{array}{l}\text { Final } \\
\delta^{15} \mathrm{~N}\end{array}$ & $\begin{array}{l}\text { Final } \\
\delta^{18} \mathrm{O}\end{array}$ & $f$ & $\mathrm{NO}_{3}^{-}$ & $\begin{array}{l}\text { Final } \\
\delta^{15} \mathrm{~N}\end{array}$ & $\begin{array}{l}\text { Final } \\
\delta^{18} \mathrm{O}\end{array}$ & $f$ \\
\hline & $\mu \mathrm{M}$ & $\%$ & $\%$ & & $\mu \mathrm{M}$ & $\%$ & $\%$ & \\
\hline Tissue & 14 & 5.1 & - & 0.26 & 14 & 1.8 & - & 0.21 \\
\hline 0 & 14 & 3.3 & 21.8 & 1.00 & 14 & 3.5 & 17.3 & 1.00 \\
\hline 12 & 9 & 4.5 & 22.4 & 0.60 & 3 & 6.3 & 23.1 & 0.22 \\
\hline 24 & 4 & 4.8 & 24.9 & 0.26 & 3 & 6.4 & 22.6 & 0.21 \\
\hline 48 & $<1$ & Lost & Lost & 0.03 & - & - & - & - \\
\hline Tissue & 60 & 6.0 & - & 0.51 & 55 & 1.2 & - & 0.24 \\
\hline 0 & 60 & 3.4 & 23.0 & 1.00 & 55 & 2.9 & 21.9 & 1.00 \\
\hline 12 & 46 & 4.1 & 24.2 & 0.76 & - & - & - & - \\
\hline 24 & 31 & 4.9 & 25.5 & 0.51 & 13 & 6.3 & 25.6 & 0.24 \\
\hline 48 & 1 & 9.5 & 30.1 & 0.02 & - & - & - & \\
\hline Tissue & 103 & 2.9 & - & 0.78 & 104 & 0.7 & - & 0.68 \\
\hline 0 & 103 & 3.2 & 23.6 & 1.00 & 104 & 3.1 & 23.3 & 1.00 \\
\hline 12 & 90 & 3.5 & 24.1 & 0.87 & - & - & - & - \\
\hline 24 & 90 & 4.1 & 24.4 & 0.78 & 71 & 5.1 & 25.1 & 0.68 \\
\hline 48 & 36 & 6.3 & 27.6 & 0.35 & - & - & - & - \\
\hline Tissue & 485 & 1.2 & - & 0.99 & 514 & -3.0 & - & 0.96 \\
\hline 0 & 485 & 3.2 & 23.2 & 1.00 & 514 & 2.7 & 23.1 & 1.00 \\
\hline 12 & 467 & 3.2 & 23.5 & 0.96 & - & - & - & - \\
\hline 24 & 481 & 2.7 & 23.1 & 0.99 & 495 & 3.1 & 23.3 & 0.96 \\
\hline 48 & 435 & 3.4 & 23.7 & 0.90 & 439 & 4.1 & 25.0 & 0.85 \\
\hline
\end{tabular}

For the tissue each analysis represents the mean of two replicates; for the $\mathrm{NO}_{3}^{-}$each analysis represents the mean of four analyses.

Table 2. $\mathrm{N}$ isotopic composition of syringe experiment algae.

\begin{tabular}{lrrrr}
\hline & $\begin{array}{r}\mathrm{NO}_{3} \\
(\mu \mathrm{m})\end{array}$ & $\begin{array}{r}\delta{ }^{15} \mathrm{~N} \\
\% \circ\end{array}$ & $\sigma$ & $n$ \\
\hline Initial & & 3.3 & 0.3 & 16 \\
Ulva & 3 & 1.3 & 0.3 & 7 \\
Agardhiella & 7 & 3.4 & 0.0 & 2 \\
Agardhiella & 10 & 2.9 & 0.0 & 2 \\
\hline
\end{tabular}

vitamins (vitamin $\mathrm{B}_{12}$, biotin and thiamine) and trace metals (Fe, Cu, Mo, Zn, Co and Mn) (Guillard, 1975). The cultures were continually aerated throughout the incubations.

\subsection{Experimental protocol}

\subsubsection{Free-drift experiments}

In these experiments the effect of varied nutrient availability on the nitrogen isotopic composition of new algal growth with respect to varied $\mathrm{NO}_{3}^{-}$concentration was investigated. Nominal concentrations of $10,50,100$ and $500 \mu \mathrm{M}$ $\mathrm{N}\left(\mathrm{NaNO}_{3}\right)$ were supplied in a medium of autoclaved, filtered $(0.2 \mu \mathrm{m}$ cartridge filter) seawater enriched with the same $\mathrm{KH}_{2} \mathrm{PO}_{4}$, B vitamin and trace metal supplements outlined for the acclimation medium (note that the actual targeted and measured concentrations were slightly different and the values used are reported in Tables 1 and 2). Subsamples of Ulva and Agardhiella (0.25-0.5 g wet weight; $2.5-3.0 \mathrm{~cm}$ ) were taken from acclimation flasks, any visible epiphytes were again removed and the algae samples were placed in $2 \mathrm{~L}$ flasks filled with incubation medium. The media were replaced every $24 \mathrm{~h}$, at which time each algal sample was rinsed to prevent epiphyte accumulation. The experiments proceeded for a period of 7-9 days. Water samples were collected after each $24 \mathrm{~h}$ period and analysed for the concentrations of $\mathrm{NO}_{3}^{-}$and $\mathrm{NH}_{4}^{+}$. At the conclusion of the incubations, final accumulated biomass was weighed and, as the new algal growth produced was clearly visible, material which had grown only under the experimental conditions was trimmed off (Fig. 1). This material was dried $\left(40^{\circ} \mathrm{C}, 48 \mathrm{~h}\right)$ and then ground with mortar and pestle for subsequent $\mathrm{N}$ isotopic analyses and $\mathrm{C} / \mathrm{N}$ determination. In order to examine the effect of assimilation on the $\delta^{15} \mathrm{~N}$ of residual $\mathrm{NO}_{3}^{-}$, special experiments were performed in which the same water was kept in the algal cultures for periods of up to $48 \mathrm{~h}$. After 


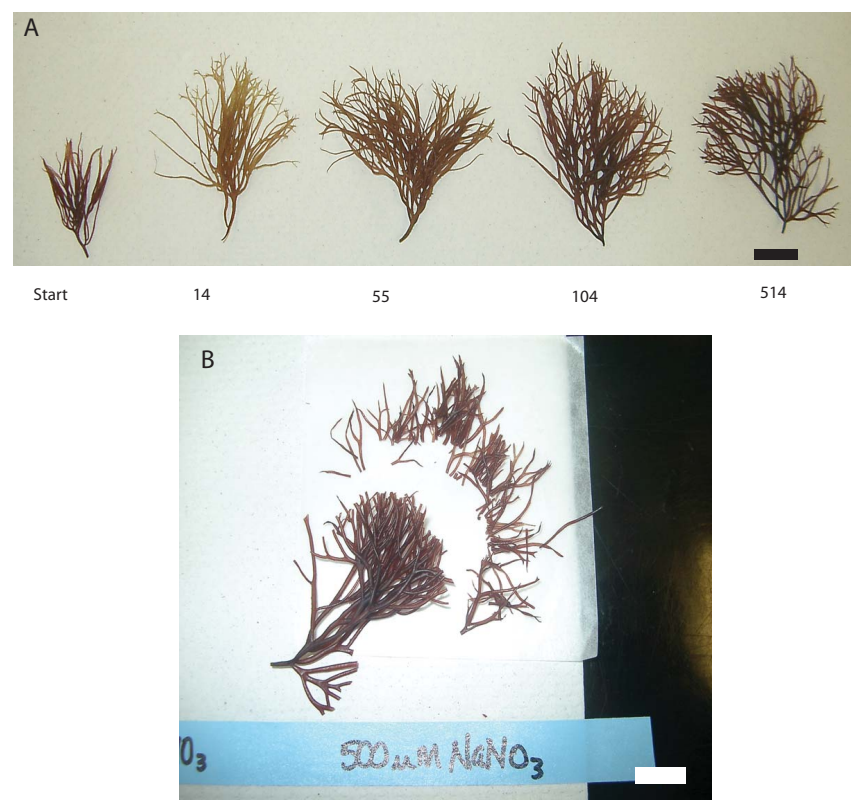

Figure 1. Pictures showing samples of Agardhiella sp. grown in different concentrations of $\mathrm{NO}_{3}^{-}$. From left to right, pictures show the initial individual and specimens grown in solutions containing nominally ambient, 10, 50, 100 and $500 \mu \mathrm{M} \mathrm{NO}_{3}^{-}$. All experiments in which $\mathrm{NO}_{3}^{-}$was added showed approximately similar growth rates, but reduced uptake of $\mathrm{N}$ at lower $\mathrm{N}$ concentrations. At the end of the experiment the ends of the algae were trimmed and analysed for their $\delta^{15} \mathrm{~N}, \delta^{13} \mathrm{C}$ and $\mathrm{C} / \mathrm{N}$ ratio. The new growth could be distinguished by comparison with the size of the original fragment (see Fig. 1a) and the change in colour.

12,24 and $48 \mathrm{~h}$, water samples were taken and the $\delta^{18} \mathrm{O}$ and $\delta^{15} \mathrm{~N}$ of the $\mathrm{NO}_{3}^{-}$measured.

\subsubsection{Constant $\mathrm{NO}_{3}^{-}$concentration experiments}

At low concentrations of $\mathrm{NO}_{3}^{-}(<10 \mu \mathrm{M})$, the algae rapidly assimilated $\mathrm{NO}_{3}^{-}$and concentrations decreased to values of less than $3 \mu \mathrm{M}$ within a few hours. In order to maintain a consistent low concentration and provide sufficient $\mathrm{NO}_{3}^{-}$for the algal growth, $\mathrm{NO}_{3}^{-}$was continuously added by means of a syringe pump. The rate of addition was initially determined by using the uptake rates calculated from the freedrift experiments and then adjusted slightly after the analysis of the $\mathrm{NO}_{3}^{-}$concentration in the experiment. In these experiments concentrations started at $\sim 10 \mu \mathrm{M}$ and stabilized at $3 \mu \mathrm{M}$ throughout the growth period.

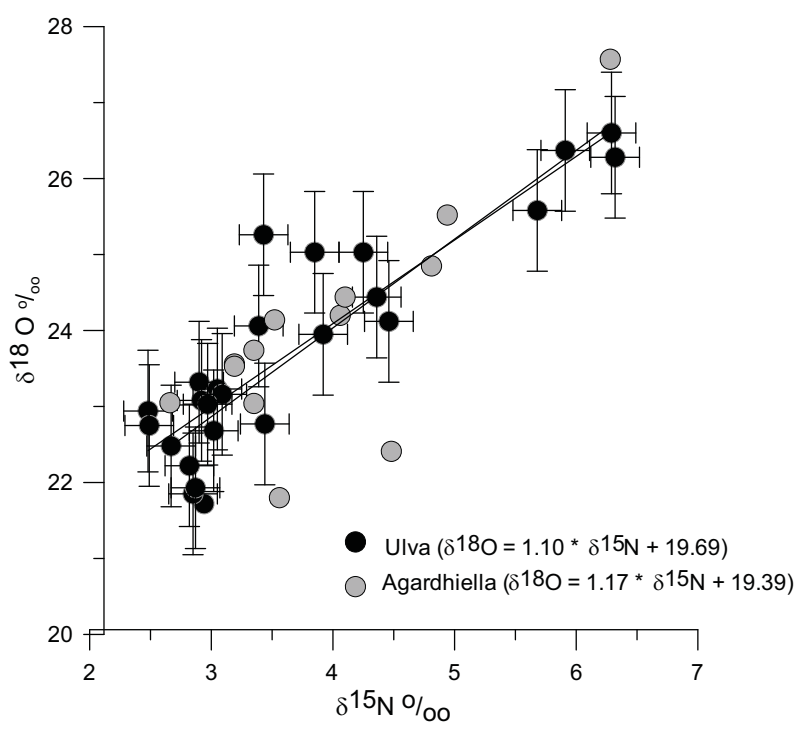

Figure 2. The relationship between $\delta^{18} \mathrm{O}$ and $\delta^{15} \mathrm{~N}$ during the freedrift experiments for the two species of algae studied. Error bars represent mean analytical error for the various analyses and have been removed for clarity from the Agardhiella sp. data.

\subsection{Analytical protocol}

\subsubsection{Stable isotopes}

\section{Algal biomass}

The organic carbon and nitrogen content as well as the stable nitrogen $\left(\delta^{15} \mathrm{~N}\right)$ and carbon $\left(\delta^{13} \mathrm{C}\right)$ isotopic composition of the algae was determined using a $\mathrm{CN}$ analyser (ANCA, Europa Scientific) interfaced with a continuous-flow isotoperatio mass spectrometer (CF-IRMS) (20-20, Europa Scientific). Prior to analysis the algae samples were dried and 3-6 mg were placed in tin capsules. Data obtained from the mass spectrometer provide the $\mathrm{C} / \mathrm{N}$ ratio of the samples in addition to the isotopic content of the organic matter. Samples of the nutrient salts added were analysed in a similar manner to determine the initial $\delta^{15} \mathrm{~N}$ of the medium. The $\delta^{15} \mathrm{~N}$ and $\delta^{18} \mathrm{O}$ of the initial $\mathrm{NO}_{3}^{-}$were also analysed as dissolved inorganic nitrogen (see below). Internal laboratory standards, calibrated to VPDB and atmospheric $\mathrm{N}_{2}$, were analysed every 10 samples, and data were corrected relative to the mean of the two nearest standards. External precision is approximately $\pm 0.2 \%$ of $\delta^{15} \mathrm{~N}$ and $\pm 0.1 \%$ ofor $\delta^{13} \mathrm{C}$. The $\mathrm{C} / \mathrm{N}$ ratio was calculated by comparing the integrated area of the major beams (mass 28 for $\mathrm{N}$ and mass 44 for $\mathrm{C}$ ) to standards with known $\mathrm{C} / \mathrm{N}$ ratios. The external precision for this method is $<0.1 \%$.

\section{Dissolved inorganic nitrogen}

The $\delta^{15} \mathrm{~N}$ and $\delta^{18} \mathrm{O}$ composition of the samples were determined using a GV IsoPrime with an external automated 
purge-and-trap system at the University of Massachusetts, Dartmouth, SMAST campus. The $\mathrm{NO}_{3}^{-}$was converted to $\mathrm{N}_{2} \mathrm{O}$ using Cd reduction to $\mathrm{NO}_{2}^{-}$followed by azide treatment (McIlvin and Altabet, 2005). Data are reported relative to atmospheric $\mathrm{N}_{2}$ and VSMOW for nitrogen and oxygen, respectively. Each run of $\mathrm{NO}_{3}^{-}$samples consisted of one operational blank (low-nutrient seawater treated with azide), three $\mathrm{NO}_{2}^{-}$standards, a cadmium blank (low-nutrient seawater treated with cadmium) and three $\mathrm{NO}_{3}^{-}$standards (USGS 34, 35 and an internal Altabet lab standard), followed by the prepared samples. Three randomly selected samples were also prepared in triplicate to check for method and machine reproducibility. The run ended with three more $\mathrm{NO}_{2}^{-}$standards, three $\mathrm{NO}_{3}^{-}$standards, a Cd blank and an operational blank. Analytical precision measured from multiple determinations on standards was approximately $\pm 0.2 \%$ o for $\delta^{15} \mathrm{~N}$ and $\pm 0.7 \%$ for $\delta^{18} \mathrm{O}\left(\mathrm{NO}_{3}^{-}\right.$only).

Isotopic data produced from each run were scrutinized for standard precision throughout individual runs. Samples were corrected for the small amount $(\sim 15 \%)$ of oxygen exchange that occurs between the sample and water during the conversion to nitrous oxide, fractionation due to oxygen removal and the $1: 1$ addition of azide $\mathrm{N}$ to $\mathrm{NO}_{2}^{-}-\mathrm{N}$ in the formation of $\mathrm{N}_{2} \mathrm{O}$ (see McIlvin and Altabet, 2005, for an in-depth discussion of $\delta^{15} \mathrm{~N}$ and $\delta^{18} \mathrm{O}$ corrections).

\section{.2 Nutrient concentrations}

Concentrations of $\mathrm{NO}_{3}^{-}, \mathrm{NO}_{2}^{-}$and $\mathrm{NH}_{4}^{+}$in the growth solutions were analysed prior to, during and after each experiment. Nitrate and nitrite concentrations were determined by diazotization before and after reduction with cadmium (Grasshoff, 1976). Ammonium concentrations were determined with the indophenol-blue method. Note that the measured concentrations of the $\mathrm{NO}_{3}^{-}$were slightly different than initial target concentrations.

\section{Results}

\subsection{Nitrogen isotopes in algal material}

\subsubsection{Free-drift experiments}

Results from the free-drift nutrient experiments from Ulva and Agardhiella are presented in Table 1. In each of the treatments the $\delta^{15} \mathrm{~N}$ of the new algal growth during each experiment and the residual $\mathrm{NO}_{3}^{-}$concentrations left in each treatment after the $24 \mathrm{~h}$ incubations were determined. Although concentrations of $\mathrm{NO}_{2}^{-}$and $\mathrm{NH}_{4}^{+}$were measured, none was detected. The $\delta^{15} \mathrm{~N}$ of the newly grown Agardhiella material decreased from $1.8 \% o(14 \mu \mathrm{M})$ to $1.6 \%$ in the $50 \mu \mathrm{M}$ treatment, to $0.7 \%$ in the $103 \mu \mathrm{M}$ treatment and finally to $-3.0 \%$ o in the $485 \mu \mathrm{M}$ experiment. Similar results were found in the experiments using Ulva although the $\delta^{15} \mathrm{~N}$ values were all higher (Table 1). For example, in the lowest two $\mathrm{NO}_{3}^{-}$treatments, the $\delta^{15} \mathrm{~N}$ of the Ulva was actually more positive than that of the $\mathrm{NO}_{3}^{-}$in the growth medium (Table 1).

The $\mathrm{C} / \mathrm{N}$ ratios and the $\delta^{13} \mathrm{C}$ values of the algae are included in the supplementary information.

\subsubsection{Syringe experiments}

The results from all the syringe experiments are listed in Table 2 . The $\delta^{15} \mathrm{~N}$ value of Ulva and Agardhiella exhibited small decreases.

\subsection{Isotopic analysis of dissolved inorganic nitrogen}

\subsubsection{Free-drift experiments}

The data from the free-drift experiments are presented in Table 1 with the trend in the $\delta^{15} \mathrm{~N}$ of the $\mathrm{NO}_{3}^{-}$mirroring that of the solid algae. The mean $\delta^{15} \mathrm{~N}$ and $\delta^{18} \mathrm{O}$ values of the initial $\mathrm{NO}_{3}^{-}$were $+3.3 \pm 0.3 \%$ and $+23 \pm 0.3$, respectively $(n=12)$, and as the $\mathrm{NO}_{3}^{-}$was consumed the residual $\mathrm{NO}_{3}^{-}$became isotopically enriched in ${ }^{15} \mathrm{~N}$ and ${ }^{18} \mathrm{O}$. The $\delta^{15} \mathrm{~N}$ and $\delta^{18} \mathrm{O}$ values in both Agardhiella sp. $\left(r^{2}=0.60, n=13\right)$ and Ulva sp. $\left(r^{2}=0.79, n=25\right)$ experiments were positively correlated to each other, exhibiting a slope close to unity for both algae species (1.1 for Ulva sp. and 1.17 for Agardhiella sp.). In the lower-concentration experiments the slope increased to approximately 2 .

\section{Discussion}

In order to calculate the fractionation during assimilation, the change in the $\delta^{15} \mathrm{~N}$ and $\delta^{18} \mathrm{O}$ of the $\mathrm{NO}_{3}^{-}$and the algal tissue was modelled using a Rayleigh distillation model. In the case of $\mathrm{N}$, the ${ }^{15} \mathrm{~N} /{ }^{14} \mathrm{~N}$ of the new algal growth (RA) at time $(t)$ is given by Eq. (3), while the ${ }^{15} \mathrm{~N} /{ }^{14} \mathrm{~N}$ of the residual $\mathrm{NO}_{3}^{-}$ $(R)$ at $t$ is given by Eq. (4).

$$
\begin{array}{r}
\mathrm{RAt}=\operatorname{Ri} \frac{1-f^{1 / \alpha}}{1-f} \\
\mathrm{Rt}=\operatorname{Ri} f^{\left(\frac{1}{\alpha}-1\right)}
\end{array}
$$

In these equations, $f$ represents the fraction of the initial $\mathrm{NO}_{3}^{-}$remaining; Ri the ${ }^{15} \mathrm{~N} /{ }^{14} \mathrm{~N}$ ratio of the initial $\mathrm{NO}_{3}^{-}$; Rt and RAt the ${ }^{15} \mathrm{~N} /{ }^{14} \mathrm{~N}$ ratio of the $\mathrm{NO}_{3}^{-}$and new algal growth, respectively, after a specific time during which $f$ has been determined; and $\alpha$ the fractionation factor. The fractionation $\left({ }^{15} \varepsilon\right)$ can also be calculated using the approach of Mariotti et al. (1981) which utilizes a plot of the isotopic composition of the $\mathrm{NO}_{3}^{-}$with respect to $\ln f$ or $\ln \left(\mathrm{NO}_{3}^{-}(t) / \mathrm{NO}_{3}^{-}(i)\right)$ as in Eq. (5).

$\delta t=\delta i-\varepsilon \ln f$

In Eq. (5), $\varepsilon\left({ }^{15} \varepsilon\right)$ is the slope of the relationship between $\delta^{15} \mathrm{Nt}$ and $\ln \mathrm{f}$. The term $\delta t$ is equal to the $\delta^{15} \mathrm{~N}$ of the $\mathrm{NO}_{3}^{-}$ 
Table 3. Calculated fractionation $(\varepsilon)$ for experiments using linear model.

\begin{tabular}{llrrrr}
\hline \# & Species & $\mathrm{NO}_{3}^{-}$ & $\mathrm{NO}_{3}^{-}$ & Nitrogen & Oxygen \\
\hline & & $\mu \mathrm{M}$ & $\varepsilon$ (solid) & $\varepsilon$ (DIN) & $\varepsilon$ (DIN) \\
& & & $\% 0$ & $\% \circ$ & \\
\cline { 3 - 6 } 1 & Ulva & 2.6 & 2.1 & & \\
2 & Ulva & 14 & -3.2 & 0.8 & 1.5 \\
2 & Ulva & 60 & -0.2 & 1.5 & 3.6 \\
2 & Ulva & 103 & 0.3 & 2.9 & 3.8 \\
2 & Ulva & 485 & 2.0 & 3.5 & 5.6 \\
1 & Agardhiella & 7 & 0 & $\mathrm{~nm}$ & $\mathrm{~nm}$ \\
1 & Agardhiella & 10 & 0.4 & $\mathrm{~nm}$ & $\mathrm{~nm}$ \\
2 & Agardhiella & 14 & 3.2 & 1.9 & $\mathrm{~nm}$ \\
2 & Agardhiella & 55 & 3.4 & 2.4 & 2.6 \\
2 & Agardhiella & 104 & 3.0 & 5.1 & 4.8 \\
2 & Agardhiella & 514 & 6.3 & 8.3 & 12.9 \\
\hline
\end{tabular}

1 represents syringe experiment; 2 represents free drift; $\mathrm{nm}$ stands for not measured.

at time $(t)$ when the concentration is equal to $\mathrm{NO}_{3}^{-}(t)$, and $\delta i$ is equal to $\delta^{15} \mathrm{~N}$ of the $\mathrm{NO}_{3}^{-}$at the initial time when the concentration is equal to $\mathrm{NO}_{3}^{-}(i)$. In the free-drift experiments where the $\delta^{15} \mathrm{~N}$ of the solution was sampled multiple times, the $\delta^{15} \mathrm{~N}$ values were measured at various concentrations as the $\mathrm{NO}_{3}^{-}$was assimilated by the algae and hence values of $\ln$ $f$ calculated. A similar approach was used to calculate ${ }^{18} \varepsilon$ using the $\delta^{18} \mathrm{O}$ data.

An alternative method for calculating the fractionation factor used the measurement of the $\delta^{15} \mathrm{~N}$ of new algal tissue as a function of the expression in Eq. (6).

As $f$ tends to 0 (all the $\mathrm{NO}_{3}^{-}$was consumed), the $\delta^{15} \mathrm{~N}$ of the algae $(\delta \mathrm{A})$ tended to approach the $\delta^{15} \mathrm{~N}$ of the initial $\mathrm{NO}_{3}^{-}$. Hence, utilizing Eq. (6), the slope of the relationship was equivalent to $(\alpha-1) \times 1000$ or $\varepsilon$.

$\delta \mathrm{A} t=\delta i+\varepsilon \frac{f \ln f}{1-f}$

In each of the experiments the slope of the line was determined by plotting the initial $\delta^{15} \mathrm{~N}$ of the $\mathrm{NO}_{3}^{-}$at a $f$ value of 0 and the measured $\delta^{15} \mathrm{~N}$ of the algae at the appropriate $f$ value corresponding to the decrease in the concentration of $\mathrm{NO}_{3}^{-}$at the end of $24 \mathrm{~h}$.

While it is possible to arrive at an estimate of fractionation using either the solid sample or the $\mathrm{NO}_{3}^{-}$data, the method of measuring the $\delta^{15} \mathrm{~N}$ of the residual $\mathrm{NO}_{3}^{-}$may provide a more accurate method for a number of reasons. First, in the case of the measurement of the $\delta^{15} \mathrm{~N}$ of the tissue in the free-drift experiments, the $f$ factor is calculated by averaging the amount of $\mathrm{NO}_{3}^{-}$utilized during a $24 \mathrm{~h}$ period. This assumes that the algae grows equally throughout the $24 \mathrm{~h}$ period, rather than perhaps faster when the $\mathrm{NO}_{3}^{-}$concentration is high and lower as the concentration is reduced. In addition, as the concentration of $\mathrm{NO}_{3}^{-}$is reduced to low concentrations, the fractiona- tion of ${ }^{15} \mathrm{~N}$ will also change (see later discussion). It might be possible to model these changes, but the interpretation would be dependent upon a number of assumptions which could not be validated with the present data set. In this regard the $\delta^{15} \mathrm{~N}$ of the tissue grown in the syringe experiments might be more reliable in providing an estimate of fractionation as a constant amount of $\mathrm{NO}_{3}^{-}$is supplied throughout the growth period, and therefore Rayleigh type modelling is unnecessary. In addition, both the syringe and the free-drift tissue measurements might suffer from the inability to precisely separate new and old algal tissue growth and the possibility of translocation of $\mathrm{N}$-bearing compounds in the algal tissue. In contrast, the $\delta^{15} \mathrm{~N}$ of the residual $\mathrm{NO}_{3}^{-}$provides a direct measurement of the fractionation during assimilation. While the results obtained between the two methods are similar, in cases where there are differences we feel that the data obtained from the $\delta^{15} \mathrm{~N}$ of the $\mathrm{NO}_{3}^{-}$provide the best estimate of fractionation.

\subsection{Modelling}

As the $\mathrm{NO}_{3}^{-}$removed from the medium was balanced by algal assimilation, isotopic fractionation produced corresponding changes in both the $\delta^{15} \mathrm{~N}$ of the residual $\mathrm{NO}_{3}^{-}$and the $\delta^{15} \mathrm{~N}$ of new algal growth. These data are reported in Table 1 , and the fractionation factors estimated for ${ }^{15} \mathrm{~N}$ (and ${ }^{18} \mathrm{O}$ when applicable) using Eqs. (5) and (6) are reported in Table 3.

\subsubsection{Ulva}

The ${ }^{15} \varepsilon$ values calculated from the $\delta^{15} \mathrm{~N}$ of the algal growth and the $\mathrm{NO}_{3}^{-}$show a decrease towards 0 with decreasing concentration of $\mathrm{NO}_{3}^{-}$(Table 3, Fig. 3). At the higher concentrations, the estimate of ${ }^{15} \varepsilon$ obtained from the algal growth $\left(\sim 3 \%\right.$ o) and that obtained from residual $\mathrm{NO}_{3}^{-} \delta^{15} \mathrm{~N}$ are statistically the same, while at the lower initial $\mathrm{NO}_{3}^{-}$concentrations values of ${ }^{15} \varepsilon$ obtained from the algal $\delta^{15} \mathrm{~N}$ are significantly lower (Fig. 4). If the observation that fractionation varies as a function of the concentration of $\mathrm{NO}_{3}^{-}$is correct, then Eq. (3) can only yield a mean estimate of ${ }^{15} \varepsilon$ as during the experiment the concentration of $\mathrm{NO}_{3}^{-}$changes considerably as it is assimilated. In fact the data from the $\mathrm{NO}_{3}^{-}$ free-drift experiment (Table 1) is best fitted by a quadratic equation confirming a change in fractionation with changing concentration (Fig. 5). Using a Chi-squared test, the improvement in the fit between the linear and non-linear model can be shown to be statistically significant at the $99 \%$ level in both the 60 and $103 \mu \mathrm{M}$ experiments. The first differential of the quadratic equation therefore provides an estimate of $\varepsilon$ at any value of $f$. Using the data from the experiments which were initiated at concentrations of 14,60 and $103 \mu \mathrm{M} \mathrm{NO}_{3}^{-}$ and calculating the mean ${ }^{15} \varepsilon$ value derived from each experiment with respect to concentration rather than $f$, a robust estimate of $\varepsilon$ with respect to changing $\mathrm{NO}_{3}^{-}$can be obtained 


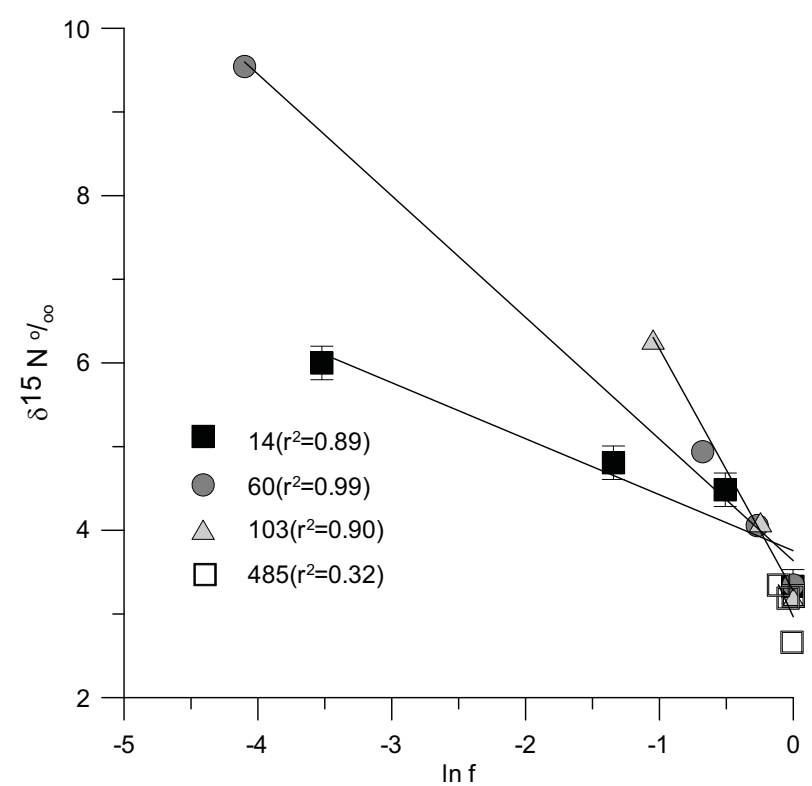

Figure 3. Calculation of ${ }^{15} \varepsilon$ using linear regression through $\delta^{15} \mathrm{~N}$ values of $\mathrm{NO}_{3}^{-}$with respect to $\ln f$ for experiments in which Ulva sp. was incubated for $48 \mathrm{~h}$. Samples of water were taken at 12, 24 and $48 \mathrm{~h}$ and measured for the concentration of remaining $\mathrm{NO}_{3}^{-}$and its $\delta^{15} \mathrm{~N}$ (and $\delta^{18} \mathrm{O}$ ). The numbers refer to the different initial concentrations of $\mathrm{NO}_{3}^{-}$used in each experiment (See Table 1).

(Fig. 6). Data from the $500 \mu \mathrm{M}$ experiment were not used in this estimate as a result of the small change in concentration of $\mathrm{NO}_{3}^{-}$(and as a consequence a small change in $f$ which occurred during the experiment at high concentration). Although the estimates of ${ }^{15} \varepsilon$ obtained from the nonlinear equation predict a value of less than 0 at concentrations lower than $\sim 1 \mu \mathrm{M}$, none of the experiments attained these low concentrations and therefore this observation will need to be confirmed. In addition the one syringe experiment performed with Ulva at a constant concentration of $\sim 3 \mu \mathrm{M}$ yielded a ${ }^{15} \varepsilon$ value of $1 \%$, higher than the values estimated from the $\mathrm{NO}_{3}^{-}$drawdown experiments. Hence such data were inconsistent with a ${ }^{15} \varepsilon$ value below 0 . In the free-drift experiments however, the $\delta^{15} \mathrm{~N}$ of the measured algae was greater than that in the initial $\mathrm{NO}_{3}^{-}(5.1$ and $4.0 \%$ in the $14 \mu \mathrm{M}$ and $60 \mu \mathrm{M}$ treatments, respectively, compared to the initial $\mathrm{NO}_{3}^{-}$ and algal values of 3.3 and $3.1 \%$, respectively) (Table 1 ), giving estimates of ${ }^{15} \varepsilon$ less than $0(\varepsilon=-3.2 \%)$. While the data of the solids appear inconsistent with the data measured on the $\delta^{15} \mathrm{~N}$ of the $\mathrm{NO}_{3}^{-}$, based on previous discussion our feeling is that assimilation factors calculated from the analysis of the $\delta^{15} \mathrm{~N}$ of the $\mathrm{NO}_{3}^{-}$are correct and that the $\delta^{15} \mathrm{~N}$ of the solid material might therefore be some kind of artefact as discussed earlier. Regardless of whether ${ }^{15} \varepsilon$ is less than 0 , both approaches show a decrease in ${ }^{15} \varepsilon$ with decreasing concentrations, and a rate of change of appears to be greatest at the lowest concentration, i.e. between 1 and $10 \mu \mathrm{M}$ (Fig. 6).

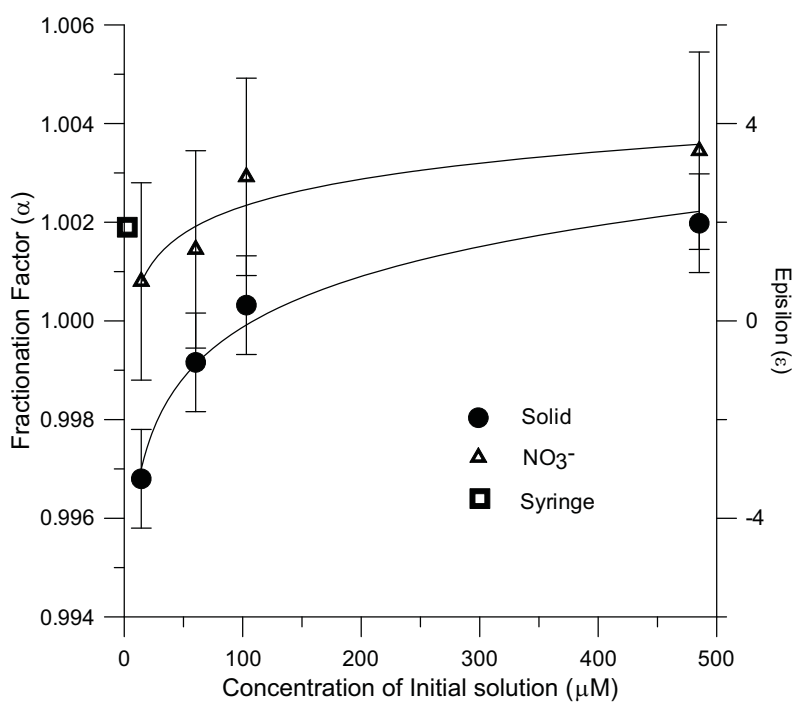

Figure 4. Estimate of fractionation factor $(\alpha)$ and $\varepsilon$ during the assimilation of $\mathrm{NO}_{3}^{-}$by Ulva sp. based on the $\delta^{15} \mathrm{~N}$ analysis of the algal material (solid) and the DIN (data from Fig. 3).

With higher concentrations (between 10 and 50 to $500 \mu \mathrm{M}$ ) the fractionation appears to reach a constant positive value $(\varepsilon=3$ to $4 \%$ ).

\subsubsection{Agardhiella}

Based on both the algal and $\mathrm{NO}_{3}^{-} \delta^{15} \mathrm{~N}$ data, this species also exhibited a strong dependence between fractionation and $\mathrm{NO}_{3}^{-}$concentration. Values of ${ }^{15} \varepsilon$ were close to 0 , or slightly negative, at low concentrations $(<10 \mu \mathrm{M})$ and increased between 100 and $500 \mu \mathrm{M}$, reaching a value of $\sim 8 \%$ o at $500 \mu \mathrm{M}$ (Fig. 7). As a result of the fact that at most only three samples were taken for measurement of the $\delta^{15} \mathrm{~N}$ (and $\delta^{18} \mathrm{O}$ ) of the $\mathrm{NO}_{3}^{-}$during the free-drift experiments, it was not considered valuable to fit anything more than a straight line to the data, and therefore a more refined equation relating the change in $\varepsilon$ to the concentration of $\mathrm{NO}_{3}^{-}$was not calculated. As in the case of Ulva, there was a suggestion that ${ }^{15} \varepsilon$ values might fall below 0 at low concentrations, although the $\delta^{15} \mathrm{~N}$ of the solid material did not increase at low $\mathrm{NO}_{3}^{-}$ concentrations as seen in Ulva sp.

\subsection{Concentration dependence of the fractionation factor}

In microalgae and bacteria the uptake and fractionation of $\mathrm{NO}_{3}^{-}$has been proposed to be a three-step process (Granger et al., 2004; Hoch et al., 1992; Karsh et al., 2012, 2014; Mariotti et al., 1982; Shearer et al., 1991): first a transport step across the cellular membrane $\left(\varepsilon_{\text {in }}\right)$, then a nitrate reductase step $\left(\varepsilon_{\mathrm{NR}}\right)$ and finally a flux out of the cell $\left(\varepsilon_{\text {out }}\right)$. The overall fractionation manifested by the organism, expressed as $\varepsilon_{\text {org }}$, is related to the influx, efflux and nitrate reductase 


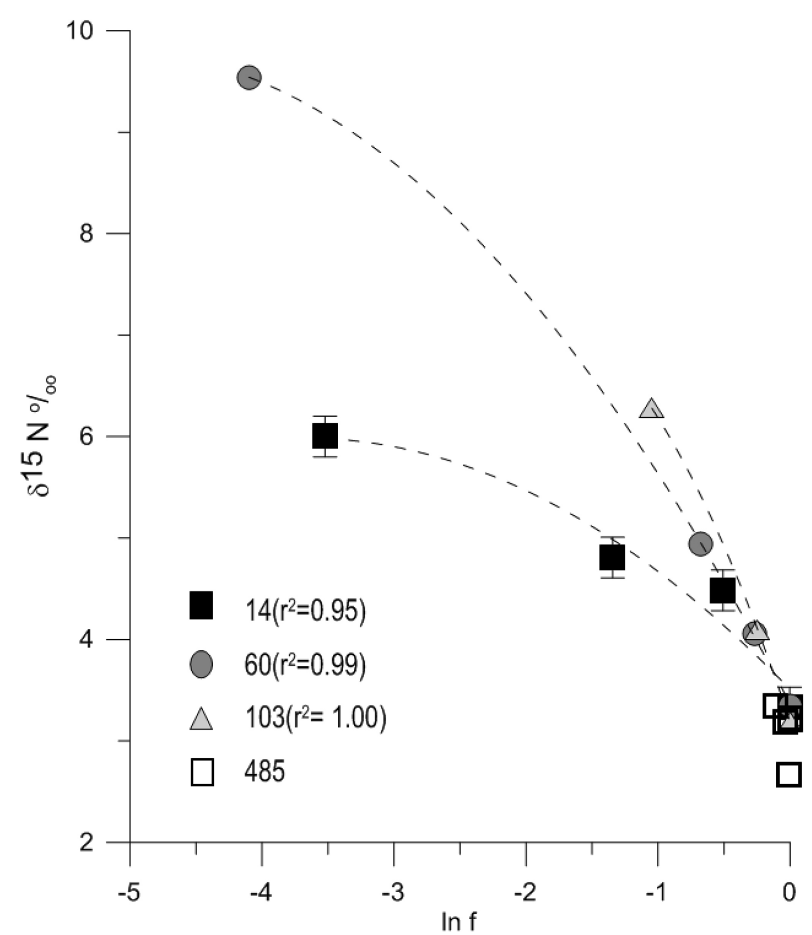

Figure 5. The changing fractionation as a consequence of decreasing $\mathrm{NO}_{3}^{-}$concentration, as shown in Fig. 3, necessitates the use of a non-linear curve fitting to the data. The use of a quadratic equation shows an improved fit to the data and allows the slope of the relationship to be calculated at specific concentrations using the first differential of the equation. Data from the $485 \mu \mathrm{M}$ experiment have been omitted as a result of the small change in the $f$ value.

fractionation by Eq. (8), in which $\gamma$ is the proportion of efflux relative to influx (Karsh et al., 2014).

$\varepsilon_{\mathrm{org}}=\varepsilon_{\mathrm{in}}+\gamma\left(\varepsilon_{\mathrm{NR}}+\varepsilon_{\mathrm{out}}\right)$

The estimated fractionation associated with these processes in a marine diatom (Thalassiosira weissflogii) are ${ }^{15} \varepsilon_{\text {in }}=2 \% o,{ }^{15} \varepsilon_{\text {out }}=1.2 \%$ and ${ }^{15} \varepsilon_{\mathrm{NR}}=26.6 \%$ o (Karsh et al., 2012, 2014). As the majority of the fractionation is associated with the NR step, the degree to which this is expressed in the external medium and also in the organism is controlled by the amount of efflux relative to influx $(\gamma)$. Accepting the possibility that there may be differences between microalgae and the organisms used in this study, we have nevertheless used this model as a basis with which to explain the observations of a concentration dependence on ${ }^{15} \varepsilon_{\text {org }}$ made in this paper. In this regard it is helpful to examine the work of Needoba et al (2004), who measured the $\delta^{15} \mathrm{~N}$ of the internal and external $\mathrm{NO}_{3}^{-}$pools. They determined that the maximum difference in $\delta^{15} \mathrm{~N}$ occurred in situations in which $\varepsilon_{\text {org }}$ was at a minimum, thus indicating that the efflux from the cell was small. Conversely when fractionation was high, the difference between the $\delta^{15} \mathrm{~N}$ of the external and internal pools

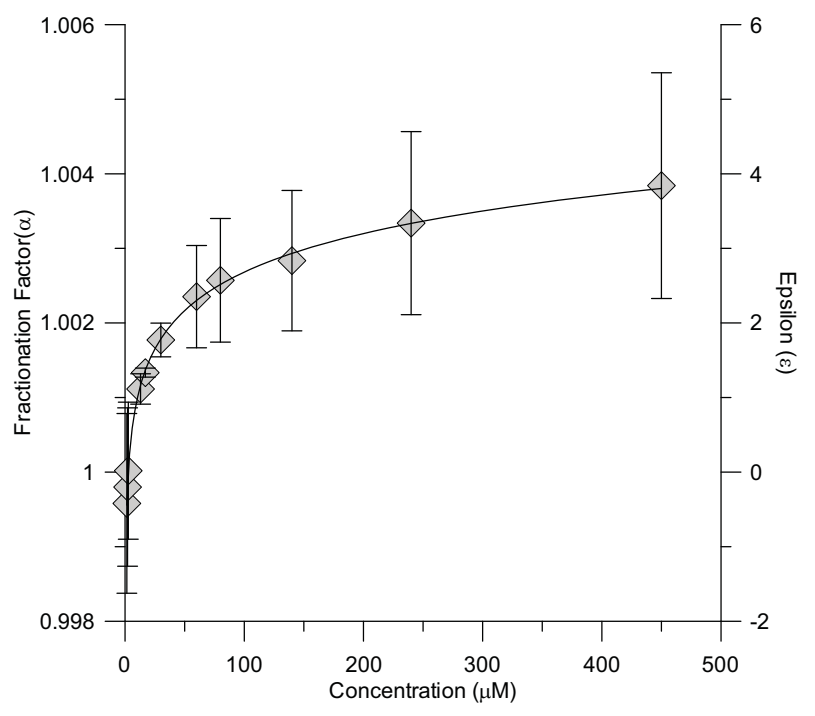

Figure 6. Average fractionation factors $(\alpha)$ and $\varepsilon$ values calculated using the mean values estimated from the first differential of the quadratic fits shown in Figure 5 for Ulva sp. Error bars represent $\pm \sigma$ of the estimate calculated using equations shown in Fig. 5.

was at a minimum and efflux maximal. As in both cases, the greatest potential for isotope fractionation is at the NR step (Karsh et al., 2012; Ledgard et al., 1985), the principal explanation for dependence on external concentration must relate to the ratio of $\mathrm{NO}_{3}^{-}$uptake to efflux from the cell. At lower external concentrations, $\mathrm{NO}_{3}^{-}$is limiting and the $\delta^{15} \mathrm{~N}$ of the internal pool is highly elevated. However, most of the $\mathrm{NO}_{3}^{-}$is consumed and efflux is minimal, and, although the same amount of fractionation at the NR step takes place, this isotopic signal is not communicated to the external environment. At high concentrations the reverse is true: $\mathrm{NO}_{3}^{-}$is not limiting, and the fractionation experienced at the NR step is translated to the external environment. Based on our findings we propose that macroalgae may behave similarly in many respects to microalgae. However, the only study we are aware of dealing with macroalgae concluded that the concentration of $\mathrm{NO}_{3}^{-}$did not influence the fractionation of ${ }^{15} \mathrm{~N}$ (Cohen and Fong, 2005) and would therefore appear to be in conflict with the results of this study. However, in the Cohen and Fong (2005) research the only experiments in which the concentration of $\mathrm{NH}_{4}^{+}$was not altered, in addition to $\mathrm{NO}_{3}^{-}$, were carried out at relatively high concentrations of $\mathrm{NO}_{3}^{-}(>50$ $\mathrm{uM})$. This is above the level at which the fractionation appeared to be constant in our study. 


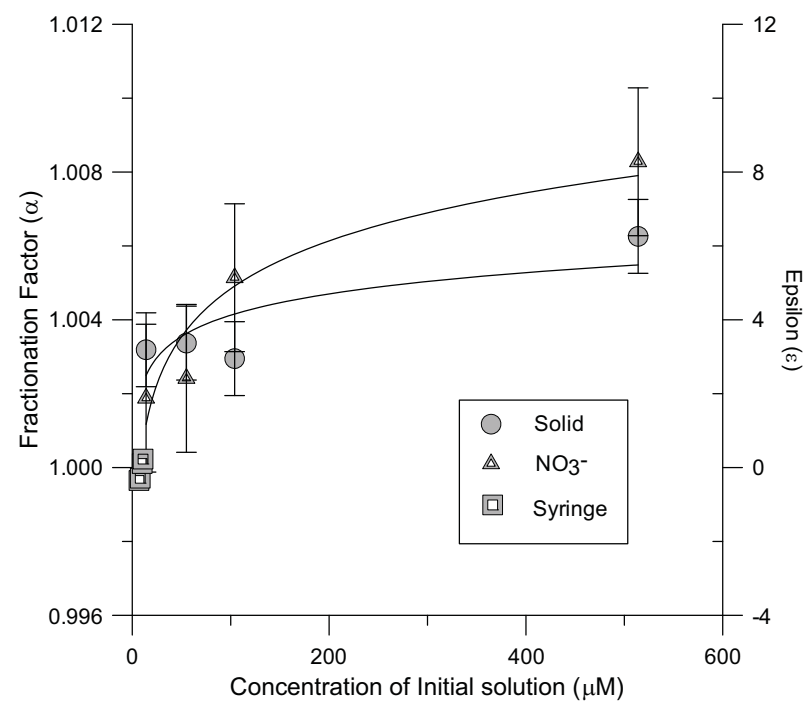

Figure 7. Estimate of fractionation $(\varepsilon)$ exerted during the incorporation of $\mathrm{NO}_{3}^{-}$into Agardhiella sp. based on the $\delta^{15} \mathrm{~N}$ analysis of the algal material and the DIN. Error bars represent $\pm \sigma$ of replicate measurements. The solid and the DIN data are based on the free-drift results.

\subsection{Oxygen isotopic composition of $\mathrm{NO}_{3}^{-}$}

The measurement of the $\delta^{18} \mathrm{O}$ of nitrate is a relatively new technique which has helped explain both the source of $\mathrm{NO}_{3}^{-}$ and the mechanism of fractionation of $\mathrm{N}$ and $\mathrm{O}$ isotopes during assimilation (Granger et al., 2004, 2010; Leichter et al., 2007; Wankel et al., 2006, 2009). The data presented here suggest that in a manner similar to ${ }^{15} \mathrm{~N}$ the fractionation of ${ }^{18} \mathrm{O}$ is dependent upon the concentration of $\mathrm{NO}_{3}^{-}$in the external environment (Tables 1 and 2; Fig. 8). While generally the fractionation of $\delta^{18} \mathrm{O}$ and $\delta^{15} \mathrm{~N}$ are related in a $1: 1 \mathrm{ra}-$ tio (Granger et al., 2004), in this study the slope of the data seems to have a value of greater than the ideal $1: 1$ relationship (Fig. 2). It was argued by Granger et al. (2004) that this $1: 1$ relationship was consistent with fractionation of $\mathrm{N}$ and $\mathrm{O}$ during $\mathrm{NR}$, whereas fractionation during uptake would give a $2: 1$ relationship. In more recent work it was shown that there are different degrees of fractionation for $\mathrm{N}$ compared to $\mathrm{O}$ during uptake and efflux, which would cause the relationship between ${ }^{18} \varepsilon$ and ${ }^{15} \varepsilon$ to rise significantly above unity, when fractionation is low (Karsh et al., 2014). Such data are in agreement with our study in that the ${ }^{18} \varepsilon:{ }^{15} \varepsilon$ ratio is closest to unity in the highest-concentration $(\sim 500 \mu \mathrm{M})$ experiments and increases with lower initial concentrations of $\mathrm{NO}_{3}^{-}$, reaching a value of $\sim 2$ at $10 \mu \mathrm{M}$. This $2: 1$ relationship corresponds to the lowest amount of fractionation observed $(\varepsilon \sim 0 \%$ ). Using the rationale suggested by Granger et al. (2004), this pattern is consistent with a change in fractionation from a process predominantly controlled by NR, to one in which fractionation is controlled by the relative difference between the fractionation of $\mathrm{O}$ and $\mathrm{N}$ during up-

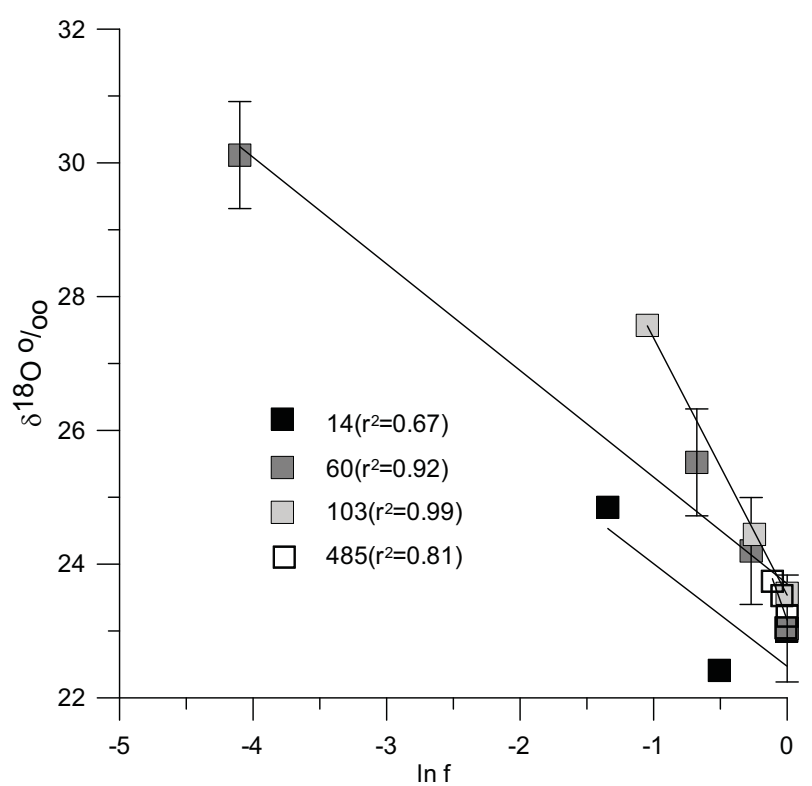

Figure 8. Relationship between the change in concentration of $\mathrm{NO}_{3}^{-}$and the $\delta^{18} \mathrm{O}$ of the $\mathrm{NO}_{3}^{-}$in the Ulva sp. free-drift experiments. Errors bars represent $\pm \sigma$ of the analytical precision on the $\delta^{18} \mathrm{O}$ measurements.

take (1.4) and efflux (2.3) (Karsh et al., 2014). If the results of these experiments are correct, then the relationship between $\delta^{18} \mathrm{O}$ and $\delta^{15} \mathrm{~N}$ also should not be linear, but rather a quadratic, similar to that observed between the $\delta^{15} \mathrm{~N}$ and concentration discussed earlier. However, as a result of the larger error on the $\delta^{18} \mathrm{O}$ compared to $\delta^{15} \mathrm{~N}(0.7$ vs. $0.2 \%$ ) , this pattern was not evident in the data collected in these experiments.

\subsection{Biogeochemical implications}

The observation of a concentration dependence upon ${ }^{15} \mathrm{~N}$ fractionation during denitrification has been previously made for microbes (Kritee et al., 2012). Both the results of that study and the data presented here suggest that there is a relationship between fractionation and concentration during assimilation, which has implications for the application of nitrogen isotopes for detection of $\mathrm{N}$ sources. It is clear that under typical N-limiting conditions both micro- and macroalgae have the same isotopic composition as the ambient nitrate. However, when $\mathrm{NO}_{3}^{-}$concentrations are elevated, algae fractionate the external $\mathrm{NO}_{3}^{-}$pool, forming biomass which is relatively isotopically more negative than the ambient $\mathrm{NO}_{3}^{-}$. The residual $\mathrm{NO}_{3}^{-}$effluxed from the cell consequently becomes isotopically more positive regardless of the $\delta^{15} \mathrm{~N}$ of the original $\mathrm{NO}_{3}^{-}$. Consider a hypothetical coastal estuary in which there is a significant input of $\mathrm{NO}_{3}^{-}$from artificial fertilizers (with a $\delta^{15} \mathrm{~N} \sim 0 \%$ ) applied to adjacent agricultural areas. As a result of the high $\mathrm{NO}_{3}^{-}$concentrations, the fractionation during assimilation by algae would be 
greater than 0 , initially producing algal material with $\delta^{15} \mathrm{~N}$ values more negative than the original $\mathrm{NO}_{3}^{-}$. As the $\mathrm{NO}_{3}^{-}$ is consumed, the $\delta^{15} \mathrm{~N}$ of the residual $\mathrm{NO}_{3}^{-}$would become more positive. Eventually isotopically positive algal material would be formed from waters which originally had a $\delta^{15} \mathrm{~N}$ close to $0 \%$. It might be incorrectly assumed in such instances that the algal material was affected by nitrogen derived from an isotopically positive source, when in fact the positive values were produced as a result of fractionation during assimilation.

\section{Conclusions}

1. There is a concentration dependence upon the fractionation of ${ }^{15} \mathrm{~N}$ and ${ }^{18} \mathrm{O}$ exerted during macroalgal assimilation of $\mathrm{NO}_{3}^{-}$. This dependence varies according to species but approaches 0 at low concentrations in both of the algal species studied here. This concentration dependence essentially means that in most open marine environments, which have $\mathrm{NO}_{3}^{-}$concentrations of less than $2 \mu \mathrm{M}$, there is minimal fractionation during assimilation. In environments with higher concentrations of $\mathrm{NO}_{3}^{-}$, the fractionation is greater than 0 , leading to enrichment in the ${ }^{15} \mathrm{~N}$ of the residual $\mathrm{NO}_{3}^{-}$regardless of the $\delta^{15} \mathrm{~N}$ of the original source of that $\mathrm{NO}_{3}^{-}$. The observation of the concentration dependence of ${ }^{15} \varepsilon$ helps to explain the wide range of values reported in the literature where experiments were carried over a wide range of $\mathrm{NO}_{3}^{-}$concentrations.

2. The change in the ${ }^{15} \varepsilon$ shows the largest rate of variation at low $\mathrm{NO}_{3}^{-}$concentrations, and there is a suggestion ${ }^{15} \varepsilon$ may fall below 0 . This might imply that organic material formed under very low $\mathrm{NO}_{3}^{-}$concentrations could manifest an inverse isotopic effect.

3. The ${ }^{18} \varepsilon$ also shows a dependence on concentration and is related to ${ }^{15} \varepsilon$ in a $1: 1$ manner at higher concentrations $(>100 \mu \mathrm{M})$ of $\mathrm{NO}_{3}^{-}$. At lower concentrations the slope of ${ }^{18} \varepsilon:{ }^{15} \varepsilon$ approaches values of $2: 1$.

4. The change of the fractionation of both ${ }^{15} \mathrm{~N}$ and ${ }^{18} \mathrm{O}$ with respect to the concentration of $\mathrm{NO}_{3}^{-}$supports a model in which there is a change in the origin of the fractionation from one in which the control is exerted by the NR step to one in which the control is exerted by difference between fractionation exerted in uptake and efflux.

\section{The Supplement related to this article is available online at doi:10.5194/bg-11-6147-2014-supplement.}

Acknowledgements. We would like to thank the staff of the Aplysia facility and the Stable Isotope Laboratory at the University of Miami. Funding for this project was provided by EPA grants to P. K. Swart. We would like to thank Quinn Devlin for assistance in the laboratory and helpful discussions. Additional funding for this project was provided by the Stable Isotope Laboratory at the University of Miami.

Edited by: B. A. Bergamaschi

\section{References}

Altabet, M. A.: A time-series study of the vertical structure of nitrogen and particle dynamics in the Sargasso Sea, Limnol. Ocean., 34, 1185-1201, 1989.

Altabet, M. A., Deuser, W. G., Honjo, S., and Stienen, C.: Seasonal and depth-related changes in the source of sinking particles in the North-Atlantic, Nature, 354, 136-139, 1991.

Barford, C. C., Montoya, J. P., Altabet, M. A., and Mitchell, R.: Steady-state nitrogen isotope effects of $\mathrm{N}_{2}$ and $\mathrm{N}_{2} \mathrm{O}$ production in Paracoccus denitrificans, Appl. Environ. Microbiol., 65, 989-994, 1999.

Carballeira, C., Viana, I. G., and Carballeira, A.: $\delta^{15} \mathrm{~N}$ values of macroalgae as an indicator of the potential presence of waste disposal from land-based marine fish farms, J. Appl. Phycol., 25, 97-107, 2013.

Cohen, R. A. and Fong, P.: Experimental evidence supports the use of $\delta^{15} \mathrm{~N}$ of the opportunistic green macroalga Enteromorpha intestinalis (Chlorophyta) to determine nitrogen sources to estuaries, J. Phy., 41, 287-293, 2005.

Costanzo, S. D., O’ Donohue, M. J., Dennison, W. C., Loneragan, N. R., and Thomas, M.: A new approach for detecting and mapping sewage impacts, Mar. Pollut. Bull., 42, 149-156, 2001.

Delwiche, C. C. and Steyn, P. L.: Nitrogen isotope fractionation in soils and microbial reactions, Env. Sci. Tech., 4, 929-935, 1970.

Deutsch, B. and Voss, M.: Anthropogenic nitrogen input traced by means of $\delta^{15} \mathrm{~N}$ values in macroalgae: Results from in-situ incubation experiments, Sci. Total Environ., 366, 799-808, 2006.

Dugdale, R. C. and Wilkerson, F. P.: The use of ${ }^{15} \mathrm{~N}$ to measure nitrogen uptake in eutrophic oceans; experimental considerations, Limnol. Ocean., 31, 673-689, 1986.

Granger, J., D. M. Sigman, J. A. Needoba, and Harrison, P. J.: Coupled nitrogen and oxygen isotope fractionation of nitrate during assimilation by cultures of marine phytoplankton, Limnol. Oceanogr., 49, 1763-1773, 2004.

Granger, J., Sigman, D. M., Prokopenko, M. G., Lehmann, M. F., and Tortell, P. D.: A method for nitrite removal in nitrate $\mathrm{N}$ and O isotope analyses, Limnol. Oceanogr.-Meth., 4, 205-212, 2006.

Granger, J., Sigman, D. M., Rohde, M. M., Maldonado, M. T., and Tortell, P. D.: $\mathrm{N}$ and $\mathrm{O}$ isotope effects during nitrate assimilation by unicellular prokaryotic and eukaryotic plankton cultures, Geochim. Cosmochim. Acta, 74, 1030-1040, 2010.

Grasshoff, K.: Methods of Seawater Analysis, Verlag Chemie, Weinheim, 1976.

Guillard, R. R. L.: Culture of phytoplankton for feeding marine invertebrates, in: Culture of Marine Invertebrate Animals, edited by: Smith, W. L. and Chanley, M. H., Plenum Press, New York, USA, 29-60, 1975. 
Haug, G. H., Pedersen, T. F., Sigman, D. M., Calvert, S. E., Nielsen, B., and Peterson, L. C.: Glacial/interglacial variations in production and nitrogen fixation in the Cariaco Basin during the last 580 kyrs, Paleocean, 13, 427-432, 1998.

Heaton, T. H.: Isotopic studies of nitrogen pollution in the hydrosphere and atmosphere: a review, Chem. Geol., 59, 87-102, 1986.

Hoch, M. P., Fogel, M. L., and Kirchman, D. L.: Isotope fractionation associated with ammonium uptake by a marine bacterium, Limnol. Ocean., 37, 1447-1459, 1992.

Hoering, T. C. and Ford, H.: The isotope effect in the fixation of nitrogen by Azotobacter, Am. J. Chem. Soc., 82, 376-378, 1960.

Horrigan, S. G., Montoya, J. P., Nevins, J. L., and McCarthy, J. J.: Natural isotopic composition of dissolved inorganic nitrogen in the Chesapeake Bay, Est. Coast. Shelf Sci., 30, 393-410, 1990.

Karsh, K. L., Granger, J., Kritee, K., and Sigman, D. M.: Eukaryotic assimilatory nitrate reductase fractionates $\mathrm{N}$ and $\mathrm{O}$ isotopes with a ratio near unity, Env. Sci. Tech., 46, 5727-5735, 2012.

Karsh, K. L., Trull, T. W., Sigman, D. M., Thompson, P. A., and Granger, J.: The contributions of nitrate uptake and efflux to isotope fractionation during algal nitrate assimilation, Geochim. Cosmochim. Acta, 132, 391-412, doi:10.1016/j.gca.2013.09.030, 2014.

Kritee, K., Sigman, D. M., Granger J., Ward, B. B., Jayakumar A., and Deutsch, C.: Reduced isotope fractionation by denitrification under conditions relevant to the ocean, Geochim. Cosmochim. Acta, 92, 243-259, 2012.

Lajtha, K. and Michener, R. H.: Stable Isotopes in Ecology and Environmental Science, Blackwell, London, 1994.

Lamb, K., Swart, P. K., and Altabet, M. A.: Nitrogen isotopic systematics in the Florida reef tract, Bull. Mar. Sci., 88, 119-146, 2012.

Lapointe, B. E., Barile, P. J., and Matzie, W. R.: Anthropogenic nutrient enrichment of seagrass and coral reef communities in the Lower Florida Keys: discrimination of local versus regional nitrogen sources, J. Exp. Mar. Biol. Ecol., 308, 23-58, 2004.

Ledgard, S. F., Woo, K. C., and Bergersen, F. J.: Isotopic fractionation during reduction of nitrate and nitrite by extracts of spinach leaves, Austral. J. Plant Phys., 12, 631-640, 1985.

Leichter, J. J., Paytan, A., Wankel, S., and Hanson, K.: Nitrogen and oxygen isotopic signatures of subsurface nitrate seaward of the Florida Keys reef tract, Limnol. Ocean., 52, 1258-1267, 2007.

Mariotti, A., Germon, J. C., Hubert, P., Kaiser, P., Letolle, R., Tardieux, A., and Tardieux, P.: Experimental-determination of nitrogen kinetic isotope fractionation: Some principles-Illustration for the denitrification and nitrification processes, Plant Soil, 62, 413-430, 1981.

Mariotti, A., Mariotti, F., Champigny, M. L., Amarger, N., and Moyse, A.: Nitrogen isotope fractionation asscoated with nitrate reductase activity and uptake of $\mathrm{NO}_{3}^{-}$by Pearl Millet, Plant Physiol., 69, 880-884, 1982.

McIlvin, M. R. and Altabet, M. A.: Chemical conversion of nitrate and nitrite to nitrous oxide for nitrogen and oxygen isotopic analysis in freshwater and seawater, Anal. Chem., 77, 5589-5595, 2005.
Miyake, Y. and Wada, E.: The isotope effect on the nitrogen in biochemical, oxidation-reduction reactions, Records of Oceanographic Works in Japan, 11, 1-6, 1971.

Montoya, J. P., Horrigan, S. G., and McCarthy, J. J.: Natural abundance of ${ }^{15} \mathrm{~N}$ in particulate nitrogen and zooplankton in the Chesapeake Bay, Mar. Ecol.-Prog. Ser., 65, 35-61, 1990.

Needoba, J. A., Waser, N. A., Harrison, P. J., and Calvert, S. E.: Nitrogen isotope fractionation in 12 species of marine phytoplankton during growth on nitrate, Mar. Ecol.-Prog. Ser., 255, 81-91, 2003.

Needoba, J. A., Sigman, D. M., and Harrison, P. J.: The mechanism of isotope fractionation during algal nitrate assimilation as illuminated by the ${ }^{15} \mathrm{~N} /{ }^{14} \mathrm{~N}$ of intracellular nitrate, J. Phy., 40, 517-522, 2004.

Pennock, J. R., Velinsky, D. J., Ludlam, J. M., Sharp, J. H., and Fogel, M. L.: Isotopic fractionation of ammonium and nitrate during uptake by Skeletonema costatum: Implications for $\delta^{15} \mathrm{~N}$ dynamics under bloom conditions, Limnol. Ocean., 41, 451-459, 1996.

Shearer, G., Schneider, J. D., and Kohl, D. H.: Separating efflux and influx components of net nitrate uptake by synechococcusR2 under steady state conditions, J. Gen. Microbiol., 137, 1179-1184, 1991.

Sigman, D. M., Lehman, S. J., and Oppo, D. W.: Evaluating mechanisms of nutrient depletion and C-13 enrichment in the intermediate-depth Atlantic during the last ice age, Paleocean., 18, 1072, doi:10.1029/2002PA000818, 2003.

Stokes, M. D., Leichter, J. J., Wing, S., and Frew, R.: Temperature variability and algal isotopic heterogeneity on a Floridian coral reef, Mar. Ecol., 32, 364-379, 2011.

Teichberg, M., Heffner, L. R., Fox, S., and Valiela, I.: Nitrate reductase and glutamine synthetase activity, internal $\mathrm{N}$ pools, and growth of Ulva lactuca: responses to long and short-term N supply, Mar. Biol., 151, 1249-1259, 2007.

Viana, I. G. and Bode, A.: Stable nitrogen isotopes in coastal macroalgae: Geographic and anthropogenic variability, Sci. Total Environ., 443, 887-895, 2013.

Wada, E. and Hattori, A.: Nitrogen isotope effects in the assimilation of inorganic nitrogenous compounds by marine diatoms, Geomicro. J., 1, 85-101, 1978.

Wankel, S. D., Kendall, C., Francis, C. A., and Paytan, A.: Nitrogen sources and cycling in the San Francisco Bay Estuary: a nitrate dual isotopic composition approach, Limnol. Ocean., 51, 1654-1664, 2006.

Wankel, S. D., Kendall, C., and Paytan, A.: Using nitrate dual isotopic composition $\left(\delta^{15} \mathrm{~N}\right.$ and $\left.\delta^{18} \mathrm{O}\right)$ as a tool for exploring sources and cycling of nitrate in an estuarine system: Elkhorn Slough, California, J. Geophys. Res. Biogeosci., 114, G01011, doi:10.1029/2008JG000729, 2009.

Waser, N. A., Yin, K. D., Yu, Z. M., Tada, K., Harrison, P. J., Turpin, D. H., and Calvert, S. E.: Nitrogen isotope fractionation during nitrate, ammonium and urea uptake by marine diatoms and coccolithophores under various conditions of $\mathrm{N}$ availability, Mar Ecol.-Prog. Ser., 169, 29-41, 1998. 